\title{
ASYMMETRIC EFFECTS OF EXCHANGE RATE ON INFLATION IN TURKEY: WHAT AGGREGATED AND DISAGGREGATED DATA REVEAL*
}

Anıl TUĞRAL ${ }^{a}$
Bilgin BARí ${ }^{b}$

\begin{abstract}
The relationship between inflation and exchange rate in the Turkish economy is remarkable. While indirect effects of exchange rate on inflation occur through the cost channel, direct effects emerge through the consumption channel. In addition, changes in the exchange rate affect pricing decisions through the indexing channel. This study examines the effects of the exchange rate on general inflation and certain subcomponents for 2003Q1-2020Q1. For this purpose, it uses linear and nonlinear ARDL models. In the linear model results, while the short-term effects of the exchange rate occur at different rates, the long-term effects are more robust. According to the estimation results of the nonlinear model, exchange rate movements (increase-decrease) in the short run cause changes at similar rates in general prices. The findings indicate that the exchange rate is the primary determinant of inflation. In the long run, this effect is more substantial. Moreover, the asymmetries in the subcomponents are striking. While the exchange rate increases are reflected in the prices, the effect of the exchange rate decreases is insignificant. The fact that similar effects are observed in the long term can be explained by the upward trend in the exchange rate. The strong relationship between exchange rate and inflation also weakens the effectiveness of the monetary policy. In order to conduct an effective monetary policy, it is necessary to solve the structural problems of the economy and improve the production structure. In addition, economic policy should consider the stability of the exchange rate.
\end{abstract}

Keywords: Inflation, Exchange Rate, Asymmetric Effects, Linear and Nonlinear ARDL

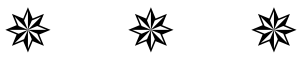 \\ TÜRKIYYE'DE DÖVIZ KURLARININ ENFLASYON ÜZERINDEKİ ASIMETRIKK ETKILERİ: BIRLEŞTİRILMIŞ VE AYRIŞTIRILMIŞ VERILERIN AÇIKLANMASI \\ Özet}

Türkiye ekonomisinde enflasyon-döviz kuru ilişkisi literatürde sıkça araştırılan konuların başında gelmektedir. Döviz kurunun enflasyon üzerinde maliyet kanalı üzerinden dolaylı etkileri, tüketim kanalı üzerinden ise doğrudan etkileri ortaya çıkmaktadır. Ayrıca, döviz kurundaki değişimler endeksleme kanalı üzerinden fiyatlama kararlarını da etkiler. Bu çalışma döviz kurunun hem genel enflasyon hem de belirli alt

\footnotetext{
*This study is developed on Anıl Tuğral's Master Thesis, "Inflation Dynamics in Turkish Economy: A Disaggregated Phillips Curve Approach", supervised by Bilgin Bari.

a Arş. Gör., Yıldız Teknik Üniversitesi, İktisadi ve İdari Bilimler Fakültesi, İktisat Bölümü, atugral@yildiz.edu.tr b Dr. Öğr. Üyesi., Anadolu Üniversitesi, İktisadi ve İdari Bilimler Fakültesi, İktisat Bölümü, bbari@anadolu.edu.tr Makale Geliş Tarihi: 26.07.2021, Makale Kabul Tarihi: 26.08.2021
} 
kalemler üzerindeki etkilerini 2003Q1-2020Q1 dönemi için inceliyor. Bu amaçla doğrusal ve doğrusal olmayan ARDL modelleri kullanıyor. Doğrusal model sonuçlarında döviz kurunun kısa dönem etkileri farklı oranlarda ortaya çıarken, uzun dönem etkiler ise daha güçlüdür. Doğrusal olmayan modelin tahmin sonuçlarına göre, kısa dönemde kur hareketleri (artış-azalış) genel fiyatlar üzerinde birbirine yakın oranlarda değişim yaratır. Bu döviz kurunun enflasyonun temel belirleyicisi olduğuna işaret ediyor. Uzun dönemde bu etki çok daha güçlü bir biçimde ortaya çıkıyor. Dahası, alt bileşenlerdeki asimetriler dikkat çekicidir. Kur artışları fiyatlara yansırken, kur düşüşlerinin etkisi anlamsız çıkmaktadır. Uzun dönemde de benzer etkilerin görülmesi kurun artış trendini sürdürmesi ile açıklanabilir. Döviz kuru ve enflasyon arasındaki güçlü ilişki para politikasının etkinliğini de zayıflatmaktadır. Etkin bir para politikası yürütülebilmesi içine ekonominin yapısal sorunlarının çözülmesi ve üretim yapısının iyileştirilmesi gereklidir. Ayrıca döviz kurunda istikrarı sağlayan bir ekonomi politikasının gerekliliği de açıktır.

Anahtar Kelimeler: Enflasyon, Döviz Kuru, Asimetrik Etkiler, Doğrusal ve Doğrusal Olmayan ARDL

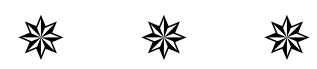

\section{Introduction}

The relationship between exchange rate and inflation is one of the most frequently studied topics in the academic literature in Turkey. In periods of fluctuations and increases in the exchange rate, the effects of the exchange rate on inflation become more robust, and the effectiveness of the monetary weakens. Although this effect has decreased after inflation targeting and floating exchange rate regime, the exchange rate is still one of the most important determinants of inflation. This effect occurs through two different channels. Exchange rate movements through the consumption channel are reflected in the prices of imported goods in the consumption basket. Changes in exchange rates directly affect consumer prices. The increase in the prices of imported intermediate goods and inputs depending on the exchange rate increases the production costs through the cost channel. In this case, an indirect effect arises from changes in the exchange rate: the first effect occurs in producer prices, then consumer prices change. What determines the aggregate effect of changes in exchange rates is the import share of consumption and the share of imported inputs in total production costs. The high share of directly imported goods or sectors using intensive imported inputs in the economy also increases the pass-through of the exchange rate. However, the effects of changes in import prices on domestic prices may be different than expected due to factors such as market conditions and the competitive environment. Atuk et al. (2014) and Ozmen and Sarıkaya (2014) remark that import prices in TL largely determine a significant part of the CPI basket in Turkey. In this sense, the pass-through effect of the exchange rate on prices has a wide sectoral spread. In addition, Taylor (2000) states that the persistence and volatility of exchange rate shocks are essential factors determining the pass-through of cost shocks to prices.

| 1096 | In addition to import and cost channels, exchange rates are also influential on pricing behavior through indexation in their interaction with inflation expectations. The interaction between exchange rates and inflation expectations can also be a determinant in pricing behavior through indexation. When the exchange rate increases, the exchange rate and inflation create a circle that feeds each other and causes the "indexation behavior" of economic units to be protected from inflation. What determines the effectiveness of the indexing behavior is the perceptions of economic agents that exchange rate shocks 
are temporary or permanent. Kara and Ogunc (2008) emphasize that the low inflation environment weakens the exchange rate-inflation relationship in Turkey.

There are also sectoral reasons that differentiate the price changes from the exchange rate and the price changes arising from the import prices. In addition to production costs, there may also be factors that affect pricing on the firm's balance sheet, such as foreign currency borrowings and firms' investment costs. Ertug et al. (2018) notice that the exchange rate pass-through is higher than the import price passthrough in the vast majority of sectors in Turkey. Apart from the cost of production, factors such as foreign currency indebtedness and investment cost can also affect the firm's balance sheet and pricing.

For Turkey, an energy importing country, the effects of exchange rates occur through two different channels. Since energy prices are determined in international markets, these prices have a variable structure and are an essential cost factor. In addition, fluctuations in the exchange rate can also affect these costs. In determining these prices, the public is an active guide, directly and indirectly (through tax policy). The fact that energy prices have a significant share in both household expenditures and the production costs of the manufacturing industry causes different effects on the subcomponents of inflation. These effects differ between consumer prices and producer prices. Ertug and Ozmen (2020) find that electricity and natural gas price adjustments have at least half as much indirect effects on inflation as their direct effects. Balkan, Kal, and Tumen (2015) reveal that besides the direct effects of fuel products on consumer inflation, they also have indirect (cost-side) effects as they are an important input in production and transportation.

This study focuses on consumer inflation and three sub-components that are effective in their determination to examine inflation dynamics. We include the effects of the exchange rate in all models to track cost-push inflation effects. For demand-pull inflationary effects, we examine credit-driven effects or the effects of monetary expansion. We consider the effects of backward-looking pricing behavior, which also shows the effectiveness of monetary policy during the inflation-targeting period. In order to explain the movements in subgroups of inflation, our models include different explanatory variables that affect the pricing behavior in the relevant groups. In addition, we analyze the exchange rate-inflation relationship in two ways by estimating the models as symmetrical and asymmetrical. In this sense, this study differs from other studies in the literature with the approach and estimation method.

The second part of the study summarizes the current studies in the literature. The third section introduces empirical framework. The fourth section explains the dataset and econometric method. The fifth section presents and interprets the prediction results. The last section includes policy analysis and policy implications.

\section{A. LITERATURE REVIEW}

Inflation dynamics have received a great deal of attention from many economists, and it has been one of the most popular topics in economics. Significantly, the persistent inflation problem of the Turkish economy encourages authors to study Turkish inflation dynamics. For example, Ergin (2015) investigates the relationship between the exchange rate and inflation in the Turkish economy by using VAR methods for the period of 2005:02-2014:12. Their findings show that the pass-through of exchange rate and import 
prices on inflation differs. Besides, Ogunc et al. (2018) analyze inflation dynamics in Turkey by using the Bayesian VAR model with quarterly data for the period of 2005Q2-2016Q2. Consistent with Ergin (2015), they find that the impact of the exchange rate on inflation is powerful and more substantial than those effects of import prices.

Also, Ozmen and Sevinc (2016) examine pricing dynamics in Turkey for the 2006-2011 period. Their results show that prices are flexible in Turkey, and pricing behavior between and within the different categories of goods and services are heterogeneous. Besides, Lopcu and Sengul (2018) analyze the impact of food prices on inflation volatility in Turkey for the 1995:01-2017:10 period. The results document that food inflation and the US dollar exchange rate significantly affect inflation volatility in Turkey. Moreover, Atuk et al. (2018) investigate the inflation dynamics in Turkey at the disaggregated level. They employ 152 subcomponents of general CPI for the 2004-2016 period with quarterly data for analyzing the sensitivity of different goods and services to the output gap. According to results, while one-third of the consumer basket is dependent on the output gap, the remaining part of price changes is mainly driven by import prices and the exchange rate pass-through effect. Ozmen and Topaloglu (2018) conducted a similar study for Turkey for the 2005-2015 period. According to findings, the responses of the 152 subcomponents of CPI are significantly affected by the exchange rate and import prices. Their results show that the pass-through in subcomponents of CPI is distinctly heterogeneous. Moreover, in addition to basic goods and energy items, there is a significant pass-through in food and services items.

Yunculer et al. (2011) demonstrate that a rise in the usage of imported input increases the sensitivity of prices to external shocks. More precisely, since Turkey is an energy-importer country, energy prices affect the inflation rate due to changes in the exchange rate rather than its prices. Also, Bari and Adali (2020) compare the effects of crude oil and gasoline prices on consumer prices. Their findings reveal that changes in both oil and fuel prices have asymmetric effects on inflation in the short run. According to their results, increases in oil prices explain the changes in consumer inflation in the long run, while the decreases in oil prices are not considered in pricing decisions.

In addition to studies that consider the case in the Turkish economy, some studies analyze inflation dynamics disaggregating the component of consumption baskets. For instance, Abdih et al. (2016) analyze inflation dynamics in the US, decomposing Personel Consumption Expenditure (PCE) into five sub-components for the 1996Q1-2015Q4 period. According to their results, domestic factors have relatively more prominent effects on the services sector, whereas foreign factors are relatively more effective in the goods sector. Besides, Lanau et al. (2018) decompose the CPI into four sub-components. They use quarterly data for the 2002-2017 period and estimate a triangular PC for Colombia using the ARDL method. They evaluate every disaggregated subcomponent of the CPI and find that the supply shocks significantly affect tradable goods and food prices while the indexation mechanism works for

| 1098 | pricing non-tradable goods.

\section{B. EMPIRICAL FRAMEWORK}

This study reveals the sources of inflation in the Turkish economy using the Modern Phillips Curve (hereafter MPC). The original Phillips curve was introduced by Phillips (1958). Then, Phelps (1967) and 
Friedman (1968) independently introduced the role expectations and NAIRU (Non-Accelerating Inflation Rate of Unemployment) to the Phillips curve. This modern framework explains inflation dynamics based on three determinants as inflation inertia, output gap, and price shocks:

$$
\pi=\pi_{t-1}+\lambda\left(y-y^{*}\right)+p
$$

where $\pi_{t-1}$ refers backward-looking inflation expectations. In general, the environment in the economy and prospects about the macroeconomic variables determines the inflation expectations. Equation (1) assumes that inflation expectations are sticky. More clearly, economic agents form their inflation expectations based on the previous months' inflation rate $\left(\pi_{t-1}\right)$. This assumption is sensible for some periods because firms consider the previous periods for pricing decisions. For instance, if an economy has experienced a high inflation trend in recent months, firms assume that this increasing trend persists. So, it affects their pricing behaviors, and they index prices in a backward-looking manner.

On the other hand, changes in the output gap $\left(y-y^{*}\right)$ affect the short-run inflation rate. In this regard, a positive output gap/excessive demand creates upward pressure on the inflation rate. This type of inflation is called demand-pull inflation since the pressure comes from aggregate demand components. When the output level converges its potential in the long run, this relationship wipes out.

The third component of the MPC captures cost-push shocks. Some changes such as a rise in input prices, decreasing productivity, or any other supply shock create upward pressure on the inflation rate. Cost-shocks are more severe than demand shocks because while the interest rate can be a panacea to adjust the demand side of the economy, supply shocks are more difficult to control by policymakers, and these shocks deteriorate both inflation and output.

The empirical framework in the study is developed on Equation (1). Unlike many other studies, we apply MPC for different sub-component of the CPI, namely food prices, housing prices, and transportation prices. These components represent more than half of the CPI in Turkey, and price changes in these groups are doubtlessly notable for the general inflation dynamics.

We employ the ARDL approach to find out the MPC for general CPI and its subcomponents. This approach has several advantages for our purposes. First, it gives inference for both short-run and longrun relationships between the dependent and independent variables. Second, it enables to find the effects of lag variables of both inflation and its determinants on the current inflation. Finally, we can use the I(0) and I(1) variables together to estimate the ARDL model. The above MPC equation can be written in ARDL form as:

$$
\pi_{t}=\alpha_{0}+\alpha_{1} \sum_{i=1}^{k} \pi_{t-i}+\alpha_{2} \sum_{i=0}^{l} x_{t-i}+\alpha_{3} \sum_{i=0}^{m} p_{t-i}+u_{t}
$$

where $x=\left(y-y^{*}\right)$. This model is called ARDL $(k, l, m)$ since it includes $k$ lags of $\pi, l$ lags of $x$, and $m$ lags of $p$. Once optimal lag numbers for variables are defined, Equation (2) can be easily estimated by OLS. Also, the following ARDL Bounds Test model developed by Pesaran and Shin (1999) and Pesaran et al. (2001) provide a basis to make inference about long-run dynamics: 


$$
\Delta \pi_{t}=\delta_{0}+\underbrace{\delta_{1} \sum_{i=1}^{k} \Delta \pi_{t-i}+\delta_{2} \sum_{i=0}^{l} \Delta x_{t-i}+\delta_{3} \sum_{i=0}^{m} \Delta p_{t-i}}_{+\mu_{t}}+\underbrace{\varphi_{1} \pi_{t-1}+\varphi_{2} x_{t-1}+\varphi_{3} p_{t-1}}_{\text {Long-rundynamics }}
$$

In Equation (3), $\delta_{i}$ refer to short-run coefficients except for constant term, $\delta_{0}$, and $\varphi_{i}$ denote longrun coefficients. If the long-run coefficients of this model $\left(\varphi_{1}, \varphi_{2}, \varphi_{3}\right)$ are mutually statistically different from zero, we can accept the existence of a long-run relationship in the model. Therefore, the following hypotheses are applied to find out if there is a cointegration in the model.

$$
\begin{array}{ll}
H_{0}: \varphi_{1}=\varphi_{2}=\varphi_{3}=0 & \text { (There is no cointegration) } \\
H_{A}: \varphi_{1} \neq \varphi_{2} \neq \varphi_{3} \neq 0 & \text { (There is a cointegration) }
\end{array}
$$

If the related $\mathrm{F}$ statistic is higher than the upper bound, which is given by the F-bound test, the null hypothesis, $H_{0}$, is rejected, and it is concluded that there is a cointegration in the model. Indeed, the regression in the Equation (3) is the unrestricted form of the following Error Correction Model (ECM):

$$
\Delta \pi_{t}=\delta_{0}+\delta_{1} \sum_{i=1}^{k} \Delta \pi_{t-i}+\delta_{2} \sum_{i=0}^{l} \Delta x_{t-i}+\delta_{3} \sum_{i=0}^{m} \Delta p_{t-i}+\varphi E C T_{t-1}+\varepsilon_{t}
$$

where ECT refers to the error correction term. In Equation (4), $\varphi E C T_{t-1}$ is replaced with the longrun coefficients of Equation (3). In ECM, the coefficient of the error correction term, $\varphi$, shows the speed of adjustment to the long-run equilibrium. In other words, it indicates the speed of the correction of the deviation from the long-run equilibrium. Because the deviation is corrected in time, $\varphi$ should be negative and individually significant for a statistically significant long-run relationship. Furthermore, $E C T_{t-1}$ denotes the lagged OLS residuals of the long-run model:

$$
E C T_{t-1}=\varepsilon_{t-1}=\pi_{t-1}-\left(\gamma_{0}+\gamma_{1} x_{t-i}+\gamma_{2} p_{t-i}\right)
$$

where $\gamma_{i}$ is the coefficient for the error correction term and gives speed of adjustment to long-run equilibrium. If the $\gamma_{i}$ is negative and less than 1 , then the $E C T_{t-1}$ gets smaller values each time. The bigger $\gamma_{i}$ refers the faster adjustment to the long-run equilibrium.

Another challenge offered by this study is to investigate whether the effect of the exchange rate on prices is nonlinear or not. In other words, we examine if both the increases and decreases in the exchange rate significantly affect prices where the exchange rate acts as the indicator of cost-shocks, $p$. For that purpose, we also estimate a nonlinear ARDL (NARDL) model developed by Shin et al. (2014).

A NARDL model separates the reactions of the dependent variable to negative and positive

| 1100 | changes in an independent variable. In the following model, $p^{+}$and $p^{-}$denote the positive and negative changes in $p$. 


$$
\pi_{t}=\theta_{0}+\theta_{1} \sum_{i=1}^{k} \pi_{t-i}+\theta_{2} \sum_{i=0}^{l} x_{t-i}+\theta_{3} \sum_{i=0}^{m} p_{t-i}^{+}+\theta_{4} \sum_{i=0}^{n} p_{t-i}^{-}+v_{t}
$$

where

$$
\begin{aligned}
& p_{t}^{+}=\sum_{j=1}^{t} \Delta p_{j}^{+}=\sum_{j=1}^{t} \max \left(\Delta p_{j}, 0\right) \\
& p_{t}^{-}=\sum_{j=1}^{t} \Delta p_{j}^{-}=\sum_{j=1}^{t} \min \left(\Delta p_{j}, 0\right)
\end{aligned}
$$

Also, the bound test model of (3) can be rewritten as

$$
\begin{aligned}
\Delta \pi_{t}=\eta_{0} & +\underbrace{\eta_{1} \sum_{i=1}^{k} \Delta \pi_{t-i}+\eta_{2} \sum_{i=0}^{l} \Delta x_{t-i}+\eta_{3} \sum_{i=0}^{m} \Delta p_{t-i}^{+}+\eta_{4} \sum_{i=0}^{n} \Delta p_{t-i}^{-}}_{\text {Short-run dynamics }} \\
& +\underbrace{\phi_{1} \pi_{t-1}+\phi_{2} x_{t-1}+\phi_{3} p_{t-1}^{+}+\phi_{4} p_{t-1}^{-}}_{\text {Long-run dynamics }}+\varepsilon_{t}
\end{aligned}
$$

Then, the hypotheses test about the long-run relationship turns into below:

$$
\begin{aligned}
& H_{0}: \phi_{1}=\phi_{2}=\phi_{3}=\phi_{4}=0 \quad \text { (There is no cointegration) } \\
& H_{A}: \phi_{1} \neq \phi_{2} \neq \phi_{34} \neq \phi_{4} \neq 0 \quad \text { (There is a cointegration) } \\
& \text { C. DATA AND ESTIMATION METHOD }
\end{aligned}
$$

This section presents the data and estimation method. We focus on the most substantial subcomponents of the CPI related to food prices, housing prices, and transportation prices. We consider them as the most vital components of the CPI because their total weight in overall CPI is \%52, and therefore, they have significant effects on overall inflation (see Table 1 and Table 2). We employ quarterly data covering the 2003Q1-2020Q1 period abstaining from using the remaining part of 2020 because the Turkish economy experienced an extraordinary episode due to the Covid-19 pandemic. The source of the data is the Electronic Data Delivery System of the Central Bank of the Republic of Turkey (CBRT). 
Table 1. Subcomponents of Consumer Price Index

\begin{tabular}{lcl}
\hline \multicolumn{1}{c}{ Subcomponents } & Weights $^{1}$ & \multicolumn{1}{c}{ Contents } \\
\hline $\begin{array}{l}\text { CPI } \mathbf{f}_{\mathbf{f}} \text { : Food and Non-Alcoholic } \\
\text { Beverages }\end{array}$ & $\% 22.77$ & $\begin{array}{l}\text { Food } \\
\text { Non-alcoholic Beverages }\end{array}$ \\
\hline $\begin{array}{l}\mathbf{C P I}_{\mathbf{h}} \text { : Housing, Water, Electricity, Gas, } \\
\text { and Other Fuels }\end{array}$ & $\% 14.34$ & $\begin{array}{l}\text { Actual Rentals for Housing } \\
\text { Maintenance and Repair of the Dwelling }\end{array}$ \\
& & $\begin{array}{l}\text { Water Supply and Miscellaneous Services Relating to the Dwelling } \\
\text { Electricity, Gas, and Other Fuels }\end{array}$ \\
\hline CPI $_{\mathbf{v}}$ : Transport & $\% 15.62$ & $\begin{array}{l}\text { Purchase of Vehicles } \\
\text { Operation of Personel Transport Equipment }\end{array}$ \\
& & Transport Services \\
\hline Total & $\% 52.73$ & \\
\hline
\end{tabular}

Source: TURKSTAT - Turkish Statictical Institute

Table 2. Descriptive Statistics of Subcomponents of CPI

\begin{tabular}{ccccc}
\hline & $\mathbf{C P I}$ & $\mathbf{C P I}_{\mathbf{f}}$ & $\mathbf{C P I}_{\mathbf{h}}$ & $\mathbf{C P I}_{\mathbf{v}}$ \\
\hline Mean & 214.51 & 231.36 & 240.01 & 209.73 \\
\hline Minimum & 96.37 & 96.93 & 97.58 & 97.14 \\
\hline Maximums & 448.35 & 539.30 & 495.29 & 424.97 \\
\hline Rate of Increases in the Related Period & 365.22 & 456.35 & 407.59 & 337.46 \\
\hline Standard Deviations & 93.90 & 116.52 & 105.19 & 89.40 \\
\hline
\end{tabular}

Our data set includes different variables that usually represent inflation, output gap, and cost shocks in equation (1). As the indicator of inflation, we employ Consumer Price Index (CPI). CPI is the convenient proxy for general inflation level because TURKSTAT (Turkish Statistic Institute) calculates the inflation rate in Turkey, which is the target of the CBRT, as the percentage change in CPI. For that reason, CPI and its selected sub-components introduce models as an indicator of the inflation rate. Moreover, because the base model of the study includes backward-looking inflation expectations, the lag values of these variables take part in models as the indicator of inertia in the ARDL models. To catch domestic demand pressures on domestic price we use stems from real money growth (M2) trend. For Turkey, there may be inflationary effects of monetary expansion-credit expansion on aggregate demand. Also, Bari (2021) points out the short-term and long-term relationship between credit cycles and business cycles. We use the output gap based on the industrial production index to include the effects from the mark-up in the model. For the seasonally adjusted industrial production index, we calculate cyclicality using the HP Filter method. By including both the output gap based on industrial production and the demand effects based on loans together into the model, we aggregate the inflationary effects stemming from the output gap.

We use the USD/TL nominal exchange rate as a main variable for each model to follow the effect of cost-push shocks on prices in Turkey. As stated in the introduction, the USD/TL rate has effects on inflation through different channels.

\footnotetext{
${ }^{1}$ Weights considers the distribution in April 2020. The current weights (by April 2021) are higher for the subcomponents that we consider. However, we limited our data set to eliminate the unusual effects of Covid-19 pandemic.
} 
In addition, USD/TL nominal exchange rate, we examine the effects of some covariates for each subcomponent. For instance, the import unit price index $(2010=100), I M P$, enters the aggregated model to reveal the effects of import prices in the general CPI. In the model of food prices, we assess the effects of the import of unprocessed food materials, $I M P_{f}$. The effect of imported prices on transportation prices is included in the sub-model with $I M P_{v}$.

We include the import price index in the model in the US dollar. Thus, they complement each other by being used together with the USD/TL rate. The dollar-based import unit index also strengthens the stability of models. Indeed, we calculate a 90\% correlation between Producer Price Index and USD/TL, highlighting the explanatory nature of the exchange rate for cost-push shocks. Europe Brent Oil Prices replaces with import prices in the model for the housing prices because this subgroup includes the energy that the households use, and prices of them (electricity, natural gas, etc.) have similar patterns with oil prices (Ertug \& Ozmen, 2020). The direct effects of energy price adjustments on inflation are proportional to the share of these products in the price index. The dollar-based oil prices and the USD/TL exchange rate complement each other here as well. Domestic natural gas price is affected by the changes in the exchange rate, as the international market prices determined by long-term contracts. Since electricity is produced mainly through natural gas power plants in Turkey, increases in natural gas producer prices affect electricity producer prices. Therefore, energy prices have a high pass-through among themselves. In addition, indirect effects of adjustments in managed energy prices on inflation can be observed through the generation and operating costs or relative prices. The increases observed in electricity prices in the industry affect the prices of the manufacturing industry through the production costs channel; this effect is then indirectly reflected in consumer prices (CBRT, 2019).

We develop different models for general inflation and its subcomponents using the above dataset:

General CPI - Model 0 (SC):

$$
C P I=\beta_{01} \sum_{i=1}^{4} C P I_{t-i}+\beta_{02} \sum_{i=0}^{0} G A P_{t-i}+\beta_{03} \sum_{i=0}^{1} M 2_{t-i}+\beta_{04} \sum_{i=0}^{0} E X C_{t-i}+\beta_{05} \sum_{i=0}^{0} I M P_{t-i}
$$

Food and Non-alcoholic Beverages - Model 1 (SC):

$$
C P I_{f}=\beta_{10}+\beta_{11} \sum_{i=1}^{3} C P I_{f_{t-i}}+\beta_{12} \sum_{i=0}^{1} G A P_{t-i}+\beta_{13} \sum_{i=0}^{1} M 2_{t-i}+\beta_{14} \sum_{i=0}^{0} E X C_{t-i}+\beta_{15} \sum_{i=0}^{1} I M P_{f_{t-i}}
$$

Housing, Water, Electricity, Gas, and Other Fuels - Model 2 (AIC):

$$
C P I_{h}=\beta_{20}+\beta_{21} \sum_{i=1}^{1} C P I_{h_{t-i}}+\beta_{22} \sum_{i=0}^{0} G A P_{t-i}+\beta_{23} \sum_{i=0}^{1} M 2_{t-i}+\beta_{24} \sum_{i=0}^{4} E X C_{t-i}+\beta_{25} \sum_{i=0}^{2} O I L_{t-i}
$$

Transport - Model 3 (SC):

$$
C P I_{v}=\beta_{30}+\beta_{31} \sum_{i=1}^{2} C P I_{v_{t-i}}+\beta_{32} \sum_{i=0}^{1} G A P_{t-i}+\beta_{33} \sum_{i=0}^{0} M 2_{t-i}+\beta_{34} \sum_{i=0}^{3} E X C_{t-i}+\beta_{35} \sum_{i=0}^{0} I M P_{v_{t-i}}
$$


Based on the Akaike Information Criteria (AIC) and Schwarz Criteria (SC), we estimate linear and nonlinear models with different lags.

\section{ESTIMATION RESULTS}

The unit root tests presented in Appendix 1 confirm that our variables can be used to estimate linear and nonlinear ARDL models. Table 3-4 present the estimation results of the models described in section 3. At first, the upper part of Table 3 indicates the results of the linear ARDL models. For the general model, statistically significant coefficients of 1 . and 4 . lagged values of the CPI have a positive sign. While three lagged inflation values are significant in model 1, first lag in model 2, and first and second lags in model 3 are significant. These results underline that backward-looking price indexation differs across all considered components of the CPI. While the effect of the output gap is insignificant in the aggregated model, the coefficients for model 1 and model 3 are significant. Especially the output gap is effective on transport prices. The 1-period lagged effects of money supply are highly effective on general prices and food and housing prices. Atuk, et al. (2014), Ozmen and Sarıkaya (2014) found that a significant portion of the CPI basket in Turkey is not sensitive to business or credit cycles. We reach similar results.

All variables react quickly to changes in exchange rates, except for house prices. As expected, the reactions in housing prices emerge after one year. This lagged effect can be explained by considering exchange rate increases in current pricing decisions. Changes in oil prices and changes in import prices capture the cost-push shock effect with significant coefficients. Let us draw attention to the fact that the effect here is due to the changes in global prices, and the exchange rate effect is combined with the total effect. 
Table 3. Estimation Results of Linear ARDL Models

\begin{tabular}{|c|c|c|c|c|}
\hline Variables & $\begin{array}{c}\text { Model 0 } \\
\text { General CPI } \\
R^{2}: 0.9994\end{array}$ & $\begin{array}{c}\text { Model } 1 \\
\text { Food prices } \\
R^{2}: 0.9979\end{array}$ & $\begin{array}{c}\text { Model } 2 \\
\text { Housing prices } \\
R^{2}: 0.9988\end{array}$ & $\begin{array}{c}\text { Model } 3 \\
\text { Transport prices } \\
R^{2}: 0.9983\end{array}$ \\
\hline \multicolumn{5}{|l|}{ Short Run } \\
\hline C & - & $\begin{array}{ll}-0.4658 & {[0.1887]}\end{array}$ & $-0.1510[0.7425]$ & $\left.\begin{array}{ll}-0.9815 & {[0.0016}\end{array}\right]$ \\
\hline CPI (-1) & $\begin{array}{ll}0.6018 \quad[0.0000]\end{array}$ & $0.8031 \quad[0.0000]$ & $\begin{array}{ll}0.8984 & {[0.0000]}\end{array}$ & $\begin{array}{ll}1.1576 & {[0.0000]}\end{array}$ \\
\hline CPI (-2) & $\begin{array}{ll}0.0708 & {[0.5651]}\end{array}$ & $\begin{array}{ll}-0.5077 & {[0.0002]}\end{array}$ & - & $\begin{array}{ll}-0.3717 & {[0.0011]}\end{array}$ \\
\hline CPI (-3) & $\begin{array}{ll}-0.1195 & {[0.3252]}\end{array}$ & $0.4801 \quad[0.0000]$ & - & - \\
\hline CPI (-4) & $0.3216 \quad[0.0010]$ & - & - & - \\
\hline GAP & $\begin{array}{ll}-0.0004 & {[0.9850]}\end{array}$ & $\begin{array}{ll}-0.1841 & {[0.0678]}\end{array}$ & $-0.0103 \quad[0.8733]$ & $0.2169[0.0047]$ \\
\hline$G A P(-1)$ & - & $0.1654 \quad[0.0858]$ & - & $\begin{array}{ll}-0.1317 & {[0.0875]}\end{array}$ \\
\hline$M 2$ & $\begin{array}{ll}-0.1133 & {[0.0065]}\end{array}$ & $-0.0955[0.3701]$ & $\begin{array}{ll}-0.2008 & {[0.0190]}\end{array}$ & $\begin{array}{ll}0.0886 & {[0.0052}\end{array}$ \\
\hline$M 2(-1)$ & $0.1280 \quad[0.0031]$ & $\begin{array}{ll}0.1827 & {[0.0570]}\end{array}$ & $0.2400 \quad[0.0021]$ & - \\
\hline$E X C$ & $0.1066 \quad[0.0000]$ & $\begin{array}{ll}0.1540 & {[0.0005]}\end{array}$ & $\begin{array}{ll}0.0416 & {[0.2554]}\end{array}$ & $0.1719 \quad[0.0000]$ \\
\hline$E X C(-1)$ & - & - & $\begin{array}{ll}0.0132 & {[0.8027]}\end{array}$ & $\begin{array}{ll}-0.0895 & {[0.0933]}\end{array}$ \\
\hline$E X C(-2)$ & - & - & $\begin{array}{ll}-0.0859 & {[0.0919]}\end{array}$ & $-0.0752 \quad[0.1457]$ \\
\hline EXC (-3) & - & - & $0.0206 \quad[0.6579]$ & $0.1046[0.0048]$ \\
\hline EXC (-4) & - & - & $\begin{array}{ll}0.0734 & {[0.0482]}\end{array}$ & - \\
\hline$I M P$ & $\begin{array}{ll}0.0893 & {[0.0000]}\end{array}$ & $\begin{array}{ll}0.1766 \quad[0.0006]\end{array}$ & - & $0.1555 \quad[0.0030]$ \\
\hline$I M P(-1)$ & - & $\begin{array}{ll}-0.1134 & {[0.0121]}\end{array}$ & - & - \\
\hline$O I L$ & - & - & $\begin{array}{ll}-0.0348 \quad[0.0310]\end{array}$ & - \\
\hline$O I L(-1)$ & - & - & $0.0814 \quad[0.0004]$ & - \\
\hline$O I L(-2)$ & - & - & $-0.0228[0.1759]$ & - \\
\hline \multicolumn{5}{|l|}{ Long Run } \\
\hline$C$ & - & $-2.0756[0.0779]$ & $-1.4868[0.6850]$ & $-4.5829[0.0000]$ \\
\hline$\overline{G A P}$ & $-0.0038[0.9850]$ & $-0.0835[0.7628]$ & $-0.1021[0.8697]$ & 0.3978 [0.0935] \\
\hline$M 2$ & $0.1178[0.0038]$ & $0.3883[0.0002]$ & $0.3855[0.1561]$ & $0.4141[0.0000]$ \\
\hline$E X C$ & $0.8519[0.0000]$ & $0.6861[0.0000]$ & $0.6205[0.0080]$ & $0.5221[0.0000]$ \\
\hline$I M P$ & $0.7138[0.0000]$ & $0.2817[0.0024]$ & - & $0.7262[0.0021]$ \\
\hline$O I L$ & - & - & $0.2337[0.440]$ & - \\
\hline
\end{tabular}

As discussed in section 3, ARDL models have come into prominence due to their quite useful features in explaining long-run dynamics. The lower part of Table 3 presents the results of the long-run models. First, except for Model 3, the effects of the output gap wholly disappear. Most importantly, these models unambiguously show that the long-run effects of the exchange rate and import unit price index on prices are dramatically significant. The effect of money supply on general prices is quite low compared to food and housing prices.

Additionally, Table 4 tabulates that the related F-statistics are clearly higher than the upper bounds. Also, the coefficients of the $E C T$, derived in equation 4 , are statistically significant with negative signs and supports cointegration or convergence toward the long run. The coefficient of -0.125 for the Model 0 suggests $12.5 \%$ movement back towards long-run equilibrium following a shock to the model, one period later. The speed ff adjustment is $22.4 \%, 10.1 \%$ and $21.4 \%$ for other models, respectively. These results assure the validity of the long-run results. 
Table 4. Results of ARDL Bounds Tests, and the Error Correction Terms

\begin{tabular}{lcccc}
\hline & Lower bound & Upper bound & F-statistic & ECT \\
\hline Model 0 & 2.26 & 3.48 & 24.36 & $-0.1251[0.0000]$ \\
\hline Model 1 & 2.56 & 3.49 & 18.23 & $-0.2244[0.0000]$ \\
\hline Model 2 & 2.56 & 3.49 & 16.03 & $-0.1015[0.0000]$ \\
\hline Model 3 & 2.56 & 3.49 & 5.90 & $-0.2141[0.0000]$ \\
\hline [ ] refers probability values. & & & &
\end{tabular}

The high $\mathrm{R}^{2}$ value of the linear models confirms that the selected explanatory variables have high explanatory power for inflation. The diagnostic test results presented in Appendix 2 report that the models do not have autocorrelation and heteroscedasticity problems. The residual terms in the models are normally distributed, and the models are set up correctly. The CUSUM and CUSUMQ graphics in Appendix 4 also confirm the stability of the models.

We also examine the asymmetric effects of the exchange rate on inflation by estimating the model in equation 6. Table 5 indicates how the negative and positive effects of the exchange rate are separated. Subscripts of the model number refer to nonlinear models. Although the statistical significance is more prominent for the $E X C^{+}$, the models do not clearly distinguish between the effects of $E X C^{+}$and $E X C^{-}$. For the short run, the symmetrical and asymmetrical effects of the exchange rate differ considerably in the models. For the general model, increase in the exchange rate have immediate effects, while the exchange rate effect on food and transport prices weakens towards a decrease. Output gap coefficients in the models are insignificant. Similarly, Bari and Adalı (2020) state that the effect of the output gap calculated based on the industrial production index on inflation is insignificant. 
Table 5. Estimation Results of Nonlinear ARDL Models

\begin{tabular}{|c|c|c|c|c|}
\hline Variables & $\begin{array}{c}\text { Model } 0_{n} \\
\text { General CPI } \\
R^{2}: 0.9994\end{array}$ & $\begin{array}{c}\text { Model } 1_{n} \\
\text { Food prices } \\
R^{2}: 0.9979\end{array}$ & $\begin{array}{c}\text { Model } 2_{n} \\
\text { Housing prices } \\
R^{2}: 0.9989\end{array}$ & $\begin{array}{c}\text { Model } 3_{n} \\
\text { Transport. prices } \\
R^{2}: 0.9986\end{array}$ \\
\hline \multicolumn{5}{|l|}{ Short Run } \\
\hline$C$ & - & $\begin{array}{ll}0.6637 & {[0.4879]}\end{array}$ & $0.4290 \quad[0.5231]$ & $0.5149 \quad[0.3344]$ \\
\hline CPI (-1) & $\begin{array}{ll}0.6038 & {[0.0000]}\end{array}$ & $\begin{array}{ll}0.7714 & {[0.0000]}\end{array}$ & $\begin{array}{ll}0.7803 \quad[0.0000] \\
\end{array}$ & $1.0368 \quad[0.0000]$ \\
\hline CPI (-2) & $0.0713 \quad[0.5676]$ & $-0.5455 \quad[0.0001]$ & - & $-0.3466 \quad[0.0008]$ \\
\hline$C P I(-3)$ & $-0.1180 \quad[0.3369]$ & $0.4722[0.0000]$ & - & - \\
\hline CPI (-4) & $0.3252 \quad[0.0015]$ & - & - & - \\
\hline GAP & $-0.0038 \quad[0.8850]$ & $\begin{array}{ll}-0.1931 & {[0.0608]} \\
\end{array}$ & $\begin{array}{ll}-0.0806 & {[0.3442]}\end{array}$ & $0.1898 \quad[0.0005]$ \\
\hline GAP (-1) & - & $0.2323 \quad[0.0213]$ & $0.1055 \quad[0.1630]$ & - \\
\hline$G A P(-2)$ & - & - & - & - \\
\hline GAP (-3) & - & - & - & - \\
\hline GAP (-4) & - & - & - & - \\
\hline$M 2$ & $\left.\begin{array}{ll}-0.1135 & {[0.0148}\end{array}\right]$ & $0.0392[0.5107]$ & $\begin{array}{ll}-0.1290 & {[0.1356]}\end{array}$ & $\begin{array}{ll}0.0108 \quad[0.7696]\end{array}$ \\
\hline$M 2(-1)$ & $0.1294 \quad[0.0034]$ & & $0.1649 \quad[0.0451]$ & - \\
\hline$E X C^{+}$ & $\begin{array}{ll}0.1036 & {[0.0000]}\end{array}$ & $0.1943[0.0004]$ & $\begin{array}{ll}0.0505 \quad[0.3007] \\
\end{array}$ & $0.2321 \quad[0.0000]$ \\
\hline$E X C^{+}(-1)$ & - & - & $\begin{array}{ll}0.1041 & {[0.1677]}\end{array}$ & $\begin{array}{ll}-0.1154 & {[0.0609]}\end{array}$ \\
\hline$E X C^{+}(-2)$ & - & - & $\begin{array}{ll}-0.1873 \quad[0.0102] \\
\end{array}$ & $\begin{array}{ll}-0.0883 & {[0.1390]}\end{array}$ \\
\hline$E X C^{+}(-3)$ & - & - & $0.0723 \quad[0.2789]$ & $0.1478 \quad[0.0007]$ \\
\hline$E X C^{+}(-4)$ & - & - & $0.0627 \quad[0.1964]$ & - \\
\hline$E X C^{-}$ & $0.1130 \quad[0.0000]$ & $0.0208 \quad[0.8537]$ & $\begin{array}{ll}-0.1621 & {[0.2069]} \\
\end{array}$ & $\begin{array}{ll}0.0087 & {[0.8513]} \\
\end{array}$ \\
\hline$E X C^{-}(-1)$ & - & - & $\begin{array}{ll}-0.0929 & {[0.5644]}\end{array}$ & - \\
\hline$E X C^{-}(-2)$ & - & - & $0.2143 \quad[0.1742]$ & - \\
\hline$E X C^{-}(-3)$ & - & - & $-0.2034 \quad[0.1731]$ & - \\
\hline$E X C^{-}(-4)$ & - & - & $0.1874 \quad[0.0824]$ & - \\
\hline$I M P$ & $0.0904 \quad[0.0000]$ & $0.1644 \quad[0.0027]$ & - & $0.1760 \quad[0.0004]$ \\
\hline$I M P(-1)$ & - & $-0.1162[0.0115]$ & - & - \\
\hline$O I L$ & - & - & $\begin{array}{ll}-0.0297 & {[0.0747]}\end{array}$ & - \\
\hline OIL (-1) & - & - & $0.0543 \quad[0.0014]$ & - \\
\hline Long Run & & & & \\
\hline$C$ & - & $2.1994[0.4633]$ & $1.9530[0.5329]$ & $1.6621[0.3396]$ \\
\hline GAP & $-0.0325[0.8860]$ & $0.1300[0.6038]$ & 0.1135 [0.7249] & $0.6127[0.0005]$ \\
\hline$M 2$ & $0.1348[0.0920]$ & $0.1301[0.5139]$ & $0.1633[0.4567]$ & $0.0349[0.7670]$ \\
\hline$\overline{E X C^{+}}$ & $0.8812[0.0001]$ & $0.6440[0.0000]$ & $0.4667[0.0000]$ & $0.5685[0.0000]$ \\
\hline$E X C^{-}$ & $0.9611[0.0363]$ & $0.0692[0.8562]$ & $-0.2583[0.4029]$ & $0.0282[0.8512]$ \\
\hline$I M P$ & $0.7683[0.0182]$ & $0.1595[0.1372]$ & - & $0.5683[0.0001]$ \\
\hline$O I L$ & - & - & 0.1119 [0.0398] & - \\
\hline
\end{tabular}

However, there is a sharp discrepancy between them in the long run. The long-run model for general CPI remarks that while increases in the exchange rate positively affect the prices, decreases in the exchange rate are more substantial. While the increase in the exchange rate has a powerful effect on subcomponents, the effects of the decrease are insignificant. It is noteworthy that the substantial relationship between exchange rate and inflation in the long run and other coefficients are insignificant. 
Besides, coefficients of the $E X C^{+}$are higher compared to those estimated for the $E X C^{-}$. That is to say, rises in the exchange rate irreversibly increase prices and cause a permanent increase in prices. Similar to the linear model, Table 6 also presents corroborative results for the significant long-run effects of explanatory variables.

Table 6. Results of Nonlinear ARDL Bounds Tests, and the Error Correction Terms

\begin{tabular}{lcccc}
\hline & Lower bound & Upper bound & F-statistic & ECT \\
\hline Model 0 & 2.14 & 3.34 & 19.89 & $-0.1176[0.0000]$ \\
\hline Model 1 & 2.39 & 3.38 & 15.61 & $-0.3017[0.0000]$ \\
\hline Model 2 & 2.39 & 3.38 & 6.62 & $-0.2196[0.0000]$ \\
\hline Model 3 & 2.39 & 3.38 & 9.77 & $-0.3098[0.0000]$ \\
\hline
\end{tabular}

[ ] refers probability values.

In Figure 1, the dynamic multiplier graphs show adjustment of asymmetry in the existing long-run quilibrium after passing to a new long-run equilibrium due to negative and positive changes in the USD/TL rate for each model for comparison. Similar effects as in estimation results emerge for general prices. While the exchange rate effect increases in food prices, transportation prices stabilize after about eight periods. The effects of the reduction for both subgroups are not very strong. In the Housing subgroup, a different pricing behavior emerges, leading to price increases in both cases.

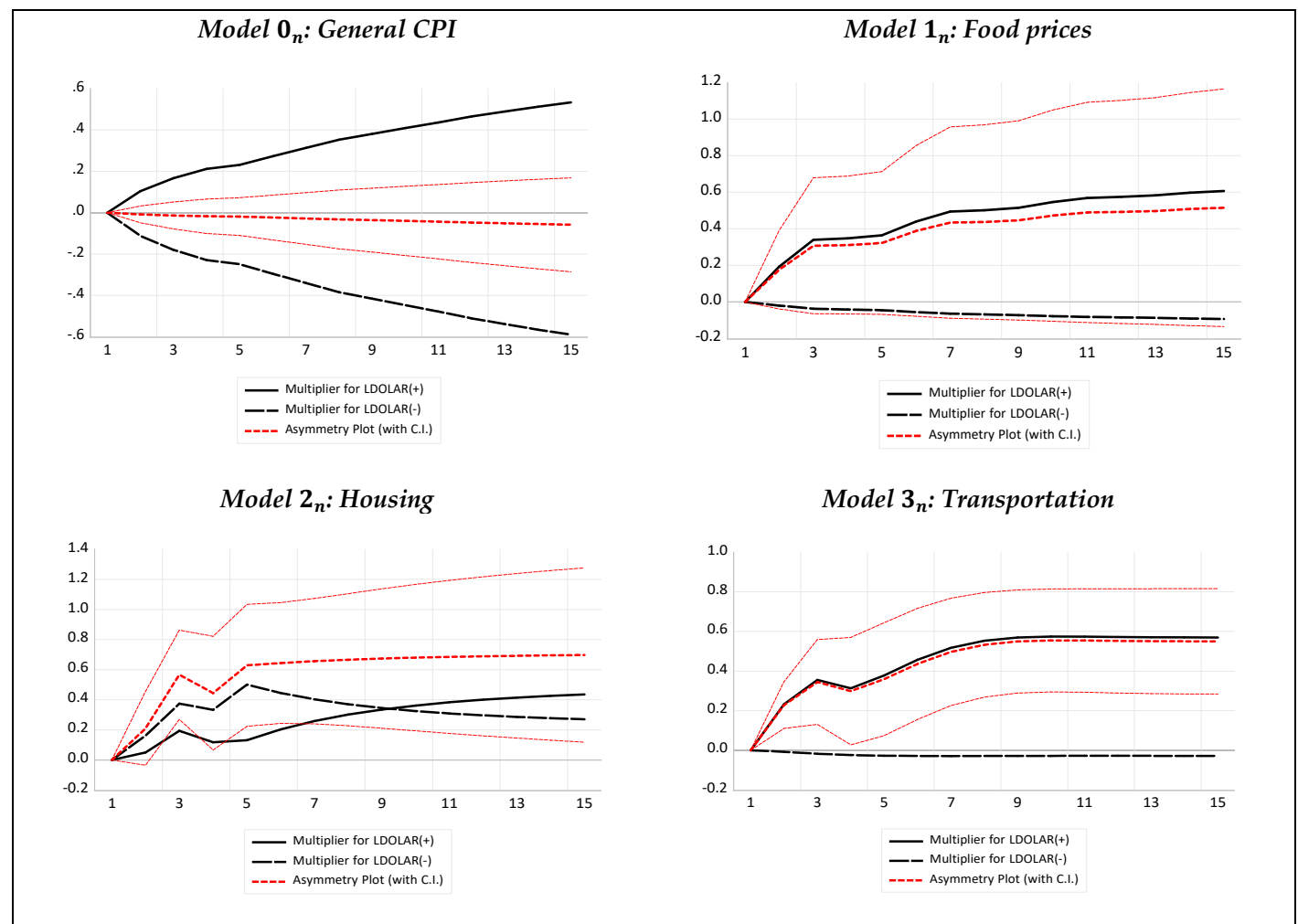

Figure 1. Multiple impacts of changes in Exchange Rate 
The high $\mathrm{R}^{2}$ value of the nonlinear models indicates that the selected explanatory variables and asymmetries have high explanatory power for inflation. The diagnostic test results presented in Appendix 3 confirm that the models are free of autocorrelation and heteroscedasticity problems. The residual terms in the models are normally distributed, and the model set up is correct. According to the CUSUM and CUSUMQ graphs in Appendix 5, the models are stable.

\section{Conclusion}

The relationship between inflation and exchange rate in the Turkish economy is one of the most frequently researched subjects in the literature. While indirect effects of exchange rate on inflation occur through the cost channel, direct effects emerge through the consumption channel. In addition, changes in the exchange rate affect pricing decisions through the indexation channel. The intensive use of imported intermediate goods and input goods in production determines the indirect effects, while the share of imported final goods in the consumption basket determines the direct effects. Exchange rate dynamics are affected by many internal and external factors. As a result, fluctuations and an upward trend occur in the exchange rate.

The effects of the exchange rate on general inflation and subcomponents differ in the abovementioned structural problems. This study examines the effects of exchange rates on both general inflation and certain subcomponents. For this purpose, we employ symmetrical and asymmetrical effects using linear and nonlinear ARDL models. In addition, short and long-term effects are tested with the help of models.

The linear model results draw attention to the existence of backward-looking pricing in the short run. This effect also emphasizes that inflation targets lose their guidance. In the short run, the output gap and real money supply also have effects on inflation. The effects of the exchange rate appear at different rates. In the long run, the exchange rate, real money supply, and import prices affect general prices. These effects differ in subcomponents. In the long run, the output gap coefficient is insignificant. This fact can be explained by the low capacity utilization and low economic growth in the industry. In other words, the capacity utilization rate cannot reach a level that will create additional costs.

The estimation results of the nonlinear model are remarkable. In the short term, the movements in the exchange rate create changes in the general prices at similar rates. The findings indicate that the exchange rate is the primary determinant of inflation. In the long run, this effect is much stronger. Interesting asymmetries are found in the subcomponents. While exchange rate increases are reflected in prices, the effect of currency decreases becomes insignificant. Similar effects are observed in the long term can be explained by the upward trend in the exchange rate.

The strong relationship between exchange rate and inflation weakens the effectiveness of the monetary policy. Failure to meet inflation targets indicates the existence of this causality. In addition to structural problems, the sharp reactions of the exchange rate to the uncertainties feed the exchange rateinflation cycle. Price stability is the main objective of the central bank. In order to administer an effective monetary policy that achieves this goal, it is necessary to solve the structural problems of the economy 
and improve the production structure. In addition, the importance of implementing an economic policy that ensures stability in the exchange rate is evident.

\section{Contribution Rate Statement}

The authors contributed equally to the article.

\section{Conflict of Interest Statement}

There is no conflict of interest between the authors.

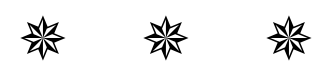




\section{APPENDIXES}

Appendix 1. Unit Root Test Results

\begin{tabular}{|c|c|c|c|c|}
\hline \multirow[b]{2}{*}{ Variables } & \multicolumn{2}{|c|}{ ADF } & \multicolumn{2}{|c|}{ PP } \\
\hline & Level & First Differences & Level & First Differences \\
\hline$C P I$ & $1.7422(0.9996)$ & $-8.1128 \quad(0.0000)$ & $1.7392(0.9996)$ & $-8.1257 \quad(0.0000)$ \\
\hline$C P I_{f}$ & $\begin{array}{ll}1.6832 & (0.9996)\end{array}$ & $\begin{array}{ll}-7.8141 \quad(0.0000) \\
\end{array}$ & $1.6832(0.9996)$ & $\begin{array}{ll}-7.8429 & (0.0000)\end{array}$ \\
\hline$C P I_{h}$ & $0.0379 \quad(0.9584)$ & $\begin{array}{ll}-6.7978 \quad(0.0000)\end{array}$ & $0.0296 \quad(0.9576)$ & $\begin{array}{ll}-6.7109 & (0.0000)\end{array}$ \\
\hline$C P I_{v}$ & $\begin{array}{ll}0.6759 & (0.9908)\end{array}$ & $\begin{array}{ll}-5.9248 & (0.0000)\end{array}$ & $0.6395 \quad(0.9899)$ & $\begin{array}{ll}-5.7255 & (0.0000)\end{array}$ \\
\hline GAP & $-3.4867 \quad(0.0113)$ & $\begin{array}{ll}-7.3441 \quad(0.0000) \\
\end{array}$ & $-3.1192(0.0298)$ & $-7.3203(0.0000)$ \\
\hline$M 2$ & $-3.8792(0.0036)$ & $-7.5898(0.0000)$ & $-4.6740(0.0003)$ & $-7.6571(0.0000)$ \\
\hline$E X C$ & $1.7360(0.9996)$ & $\begin{array}{ll}-7.2414 \quad(0.0000) \\
\end{array}$ & $\begin{array}{ll}1.8119 & (0.9997)\end{array}$ & $\begin{array}{ll}-7.2320 & (0.0000)\end{array}$ \\
\hline$O I L$ & $\begin{array}{ll}-2.8656 & (0.0548)\end{array}$ & $\begin{array}{ll}-5.8287 & (0.0000)\end{array}$ & $\begin{array}{ll}-2.2204 & (0.2011)\end{array}$ & $\begin{array}{ll}-6.3417 & (0.0000)\end{array}$ \\
\hline$I M P$ & $-2.8814(0.0529)$ & $-5.0511 \quad(0.0001)$ & $-2.4006(0.1454)$ & $-4.2760 \quad(0.0011)$ \\
\hline$I M P_{f}$ & $-1.9619 \quad(0.3027)$ & $-5.2522(0.0000)$ & $-2.0165 \quad(0.2792)$ & $-4.2680 \quad(0.0011)$ \\
\hline$I M P_{v}$ & $\begin{array}{ll}-3.0574 & (0.0347)\end{array}$ & $\begin{array}{ll}-9.3650 & (0.0000)\end{array}$ & $\begin{array}{ll}-3.0283 & (0.0372)\end{array}$ & $\begin{array}{ll}-9.6007 & (0.0000)\end{array}$ \\
\hline
\end{tabular}

( ) refers probability values.

Appendix 2. Diagnostic Test Results for Linear ARDL Models

\begin{tabular}{|c|c|c|c|c|}
\hline & Model 0 & Model 1 & Model 2 & Model 4 \\
\hline \multicolumn{5}{|l|}{ Autocorrelation } \\
\hline$L M(1)$ & $0.8503 \quad[0.3605]$ & $0.5101 \quad[0.4781]$ & [0.9401] & $0.3291 \quad[0.5686]$ \\
\hline$L M(2)$ & $0.4204 \quad[0.6589]$ & $0.3786 \quad[0.6866]$ & $0.5028 \quad[0.6078]$ & $0.2112 \quad[0.8102]$ \\
\hline \multicolumn{5}{|c|}{ Heteroscedasticity } \\
\hline$A R C H(1)$ & $0.2940 \quad[0.5896]$ & $0.8041 \quad[0.3733]$ & $0.8026 \quad[0.3738]$ & $1.1483[0.2880]$ \\
\hline$A R C H(2)$ & $0.1292[0.8790]$ & $0.3689[0.6930]$ & $2.8786 \quad[0.0640]$ & $1.5509 \quad[0.2203]$ \\
\hline Normality J-B & $\begin{array}{ll}1.3867 & {[0.4998]}\end{array}$ & $0.7230 \quad[0.6966]$ & $11.911 \quad[0.0025]$ & $0.2896 \quad[0.8651]$ \\
\hline Ramsey RESET & $0.0776 \quad[0.7815]$ & $2.0507 \quad[0.1579]$ & [0.7545] & $0.3245[0.5712]$ \\
\hline
\end{tabular}

Appendix 3. Diagnostic Test Results for Nonlinear ARDL Models

\begin{tabular}{|c|c|c|c|c|}
\hline & Model $0_{n}$ & Model $1_{n}$ & Model $2 n$ & Model 3n \\
\hline \multicolumn{5}{|l|}{ Autocorrelation } \\
\hline$L M(1)$ & $\begin{array}{ll}0.7819 & {[0.3805]}\end{array}$ & $\begin{array}{ll}0.2692 & {[0.6060]}\end{array}$ & $\begin{array}{ll}0.0025 & {[0.9603]}\end{array}$ & $0.1092 \quad[0.7423]$ \\
\hline$L M(2)$ & $0.3845 \quad[0.6827]$ & $0.1441 \quad[0.8661]$ & $0.4429 \quad[0.6450]$ & $0.1156 \quad[0.8910]$ \\
\hline \multicolumn{5}{|c|}{ Heteroscedasticity } \\
\hline$A R C H(1)$ & $0.3229[0.5719]$ & $0.7500 \quad[0.3898]$ & $0.3323 \quad[0.5664]$ & $1.7321 \quad[0.1930]$ \\
\hline$A R C H(2)$ & 0.1392 [0.8703] & $0.4366 \quad[0.6482]$ & $1.8487 \quad[0.1664]$ & 0.8663 [0.4257] \\
\hline Normality J-B & $1.1037 \quad[0.5758]$ & $0.3181 \quad[0.8529]$ & $1.3264 \quad[0.5151]$ & $0.4610 \quad[0.7941]$ \\
\hline Ramsey RESET & $0.1700 \quad[0.6817]$ & $0.6867[0.4109]$ & $0.1362 \quad[0.7137]$ & $0.5460 \quad[0.4632]$ \\
\hline
\end{tabular}


Anıl TUĞRAL \& Bilgin BARI

Appendix 4. CUSUM and CUSUMQ Results for Linear ARDL Models
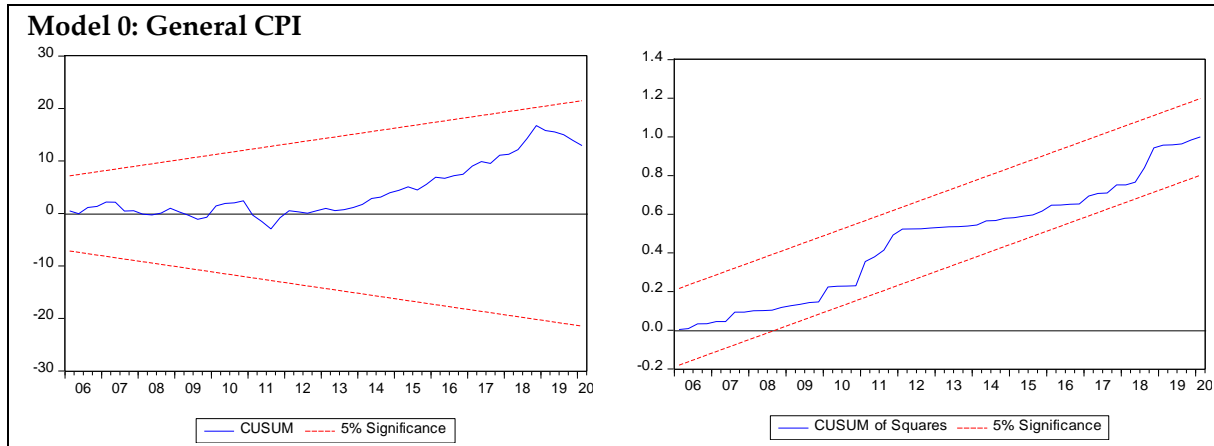

Model 1: Food prices
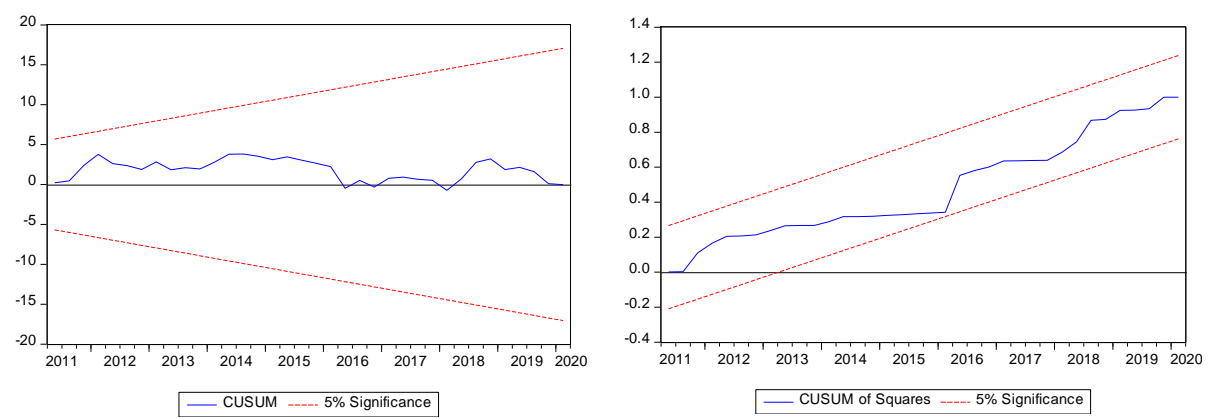

Model 2: Housing
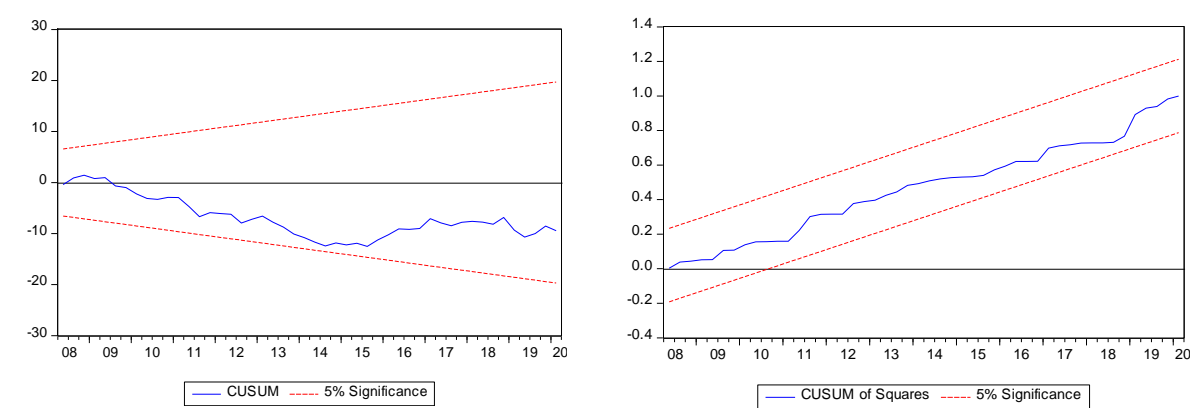

Model 3: Transportation
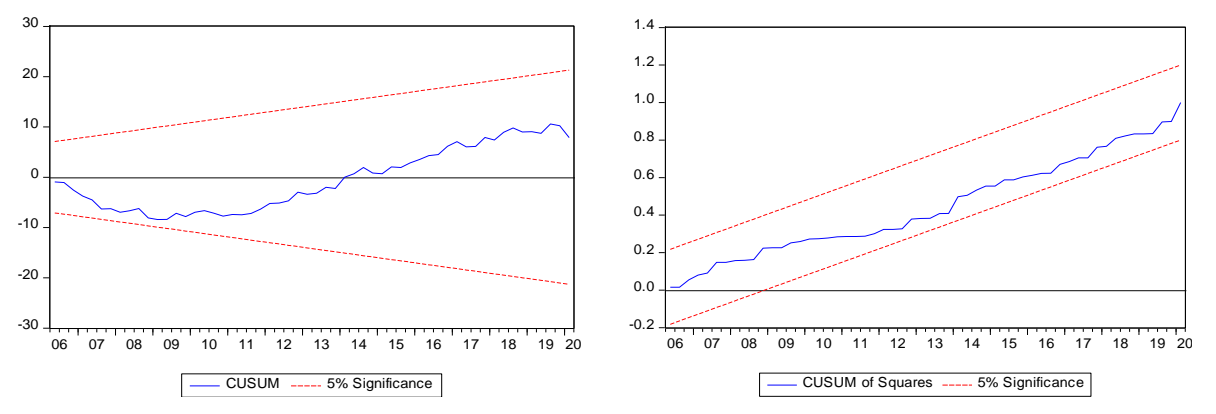
Appendix 5. CUSUM and CUSUMQ Results for Nonlinear ARDL Models
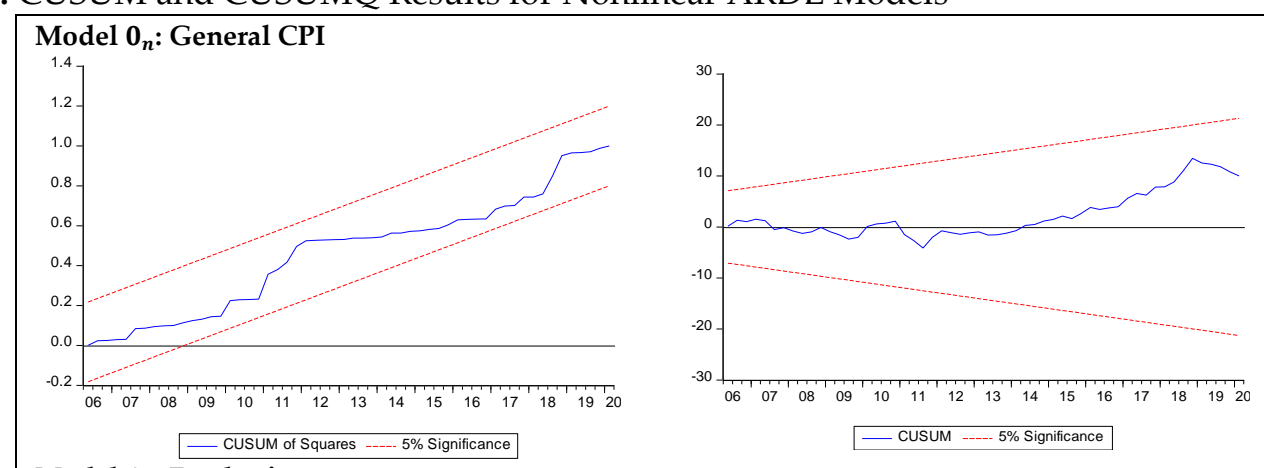

Model $1_{n}$ : Food prices

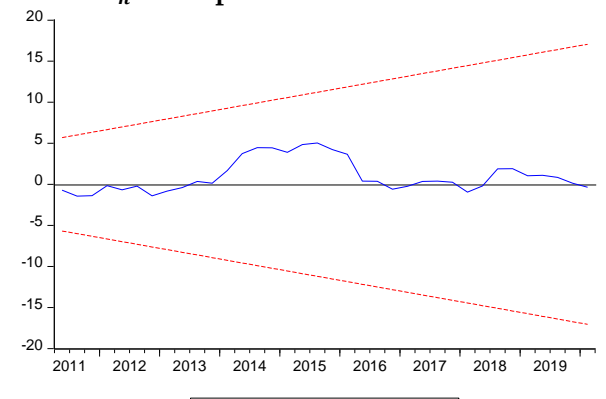

- CUSUM ---. $5 \%$ Significance

Model 2 ${ }_{n}$ : Housing
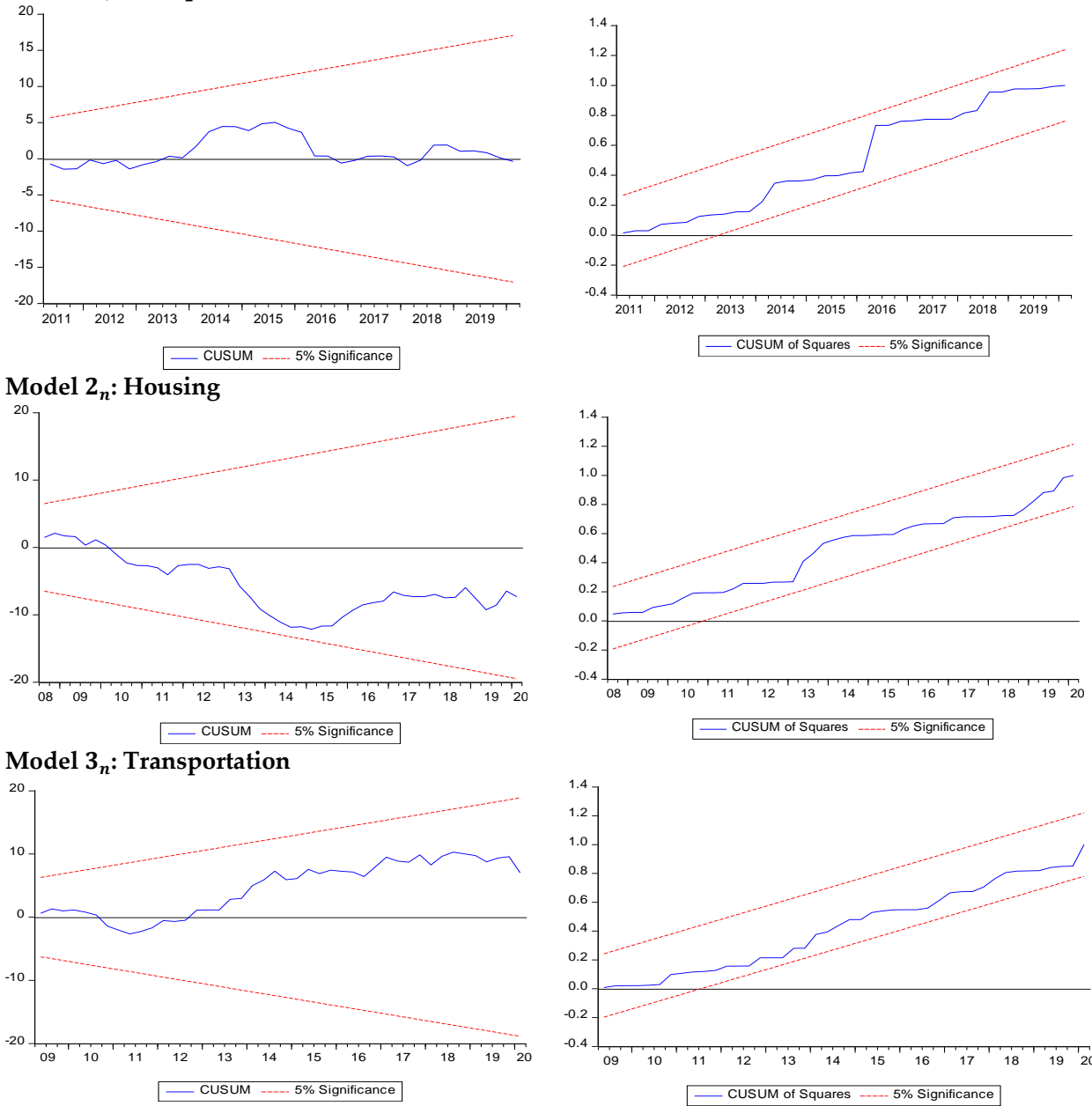

Model $3_{n}$ : Transportation

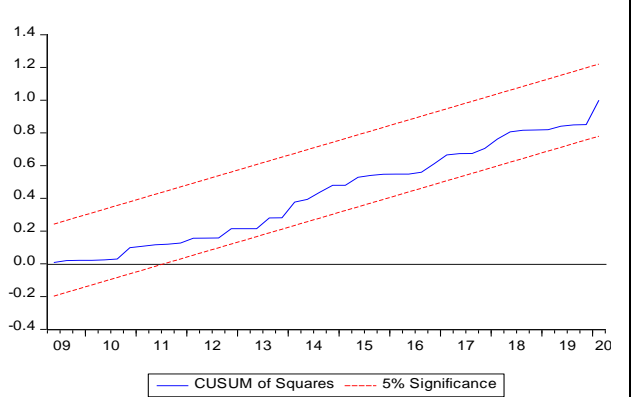

淡济 


\section{Kaynakça}

Abdih, Y., Balakrishnan, R., \& Shang, B. (2016). What is keeping U.S. core inflation low: Insights from a bottom-up approach. IMF Working Papers, 16(124).

Atuk, O., Aysoy, C., Ozmen, M. U., \& Sarıkaya, C. (2014). Sensitivity of inflation to business cycles in Turkey: Determining CPI sub-items sensitive to output gap. CBRT Working Paper, 14(37).

Atuk, O., Ozmen, M. U., \& Sarıkaya, C. (2018). A disaggregated analysis of the impact of output gap on inflation and implications for monetary policy. Prague Economic Papers, 27(6), 668-683.

Balkan, B., Kal, S. H., \& Tumen, S. (2015). Investigating the effect of fuel prices on fresh fruit and vegetable prices through the transportation cost channel. CBRT Research Notes in Economics, 2015(08).

Bari, B. (2021). Credit cycles and business cycles in Turkish economy. In S. Karabulut (Ed.). İktisadi, Mali ve Finansal Uygulamaların Ampirik Sonuçları (pp. 145-159). Gazi Kitabevi.

Bari, B., \& Adall, Z. (2020). How oil prices drive inflation in Turkish economy: Two different channels. Fiscaoeconomia, 4(3), 705-721.

CBRT (2019). Inflation Report 2019-III. https://www.tcmb.gov.tr/wps/wcm/connect/EN/TCMB+EN/Main+Menu/Publications/Reports/Inf lation+Report/2019/Inflation+Report+2019+-+III

Ergin, A. (2015). Döviz kuru ve enflasyon arasındaki geçiş etkisi: Türkiye örneği. Niğde Üniversitesi İktisadi ve İdari Bilimler Fakültesi Dergisi, 8(3), 13-29.

Ertug, D., Ozlu, P., \& Yunculer, C. (2018). How does the use of imported inputs affect exchange rate and import price pass-through?. CBRT Blog. https://tcmbblog.org/wps/wcm/connect/blog/en/main+menu/analyses/exchange+rate+passthrough

Ertug, D., \& Ozmen, M. U. (2020). Indirect effects of electricity and natural gas price increases on consumer prices.

CBRT

Blog. https://tcmbblog.org/wps/wcm/connect/blog/en/main+menu/analyses/indirect+effects+of+electrici ty+and+natural+gas+price+increases+on+consumer+prices

Friedman, M. (1968). The role of monetary policy. The American Economic Review, 58(1), 1-17.

Kara, H., \& Ogunc, F. (2008). Inflation targeting and exchange rate pass-through: The Turkish experience. Emerging Markets Finance and Trade, 44(6), 52-66.

Lanau, S., Robles, A., \& Toscani, F. (2018). Explaining inflation in Colombia: A disaggregated phillips curve approach. IMF Working Papers, 18(106).

Lopcu, K., \& Sengul, S. (2018). Is the food price volatility responsible for inflation volatility? An investigation for Turkey. Topics in Middle East and African Economies, 20(2), 105-124.

Ogunc, F., Ozmen, M. U., \& Sarıkaya, C. (2018). Inflation dynamics in Turkey from a bayesian perspective. CBRT Working Paper, 18(10). 
Ozmen, M. U., \& Topaloglu, M. (2017). Disaggregated evidence for exchange rate and import price passthrough in the light of identification issues, aggregation bias and heterogeneity. CBRT Working Paper, 17(08).

Ozmen, M. U., \& Sarıkaya, C. (2014). Enflasyonun çıktı açığı ve kredilere duyarlılığı. TCMB Ekonomi Notlarl, 2014(17).

Ozmen, M. U., \& Sevinc, O. (2016). Price rigidity in Turkey: Evidence from micro data. Emerging Markets Finance and Trade, 52(4), 1029-1045.

Pesaran, M. H., \& Shin, Y. (1999). An autoregressive distributed lag modelling approach to cointegration analysis. In S. Strom (Ed.). Econometrics and Economic Theory in the 20th Century: The Ragnar Frisch Centennial Symposium (pp. 371-413). Cambridge University Press.

Pesaran, M. H., Shin, Y., \& Smith, R. J. (2001). Bounds testing approaches to the analysis of level relationships. Journal of Applied Econometrics, 16(3), 289-326.

Phelps, E. S. (1967). Phillips curves, expectations of inflation and optimal unemployment over time. Economica, 34(135), 254-281.

Phillips, A. W. (1958). The relation between unemployment and the rate of changes of money wage rates in the United Kingdom, 1861-1957. Economica, 25(100), 283-299.

Shin, Y., Yu., B., \& Greenwood-Nimmo, M. (2014). modelling asymmetric cointegration and dynamic multipliers in a nonlinear ARDL framework. In R. Sickles \& W. Horrace (Eds.). Festschrift in Honor of Peter Schmidt (pp. 281-314). Springer.

Taylor, J. B. (2000). Low inflation, pass-through, and the pricing power of firms. European Economic Review, 44(7), 1389-1408.

Yunculer, C. (2011). Pass-through of external factors into price indicators in Turkey. Central Bank Review, 11(2), 71-84.

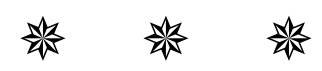

